研究

\title{
磁石粉末の磁場中配向
}

\author{
槇田顕，高木 繁 \\ 住友特殊金属侏研究開発センタ, $=$ 618-0013 大阪府三島郡島本町江川 2-15-17.
}

\section{Magnetic Alignment of Permanent Magnet Powder}

\section{Ken Makita and Shigeru Takaki}

Research \& Development Center, Sumitomo Special Metals Co., Ltd., 2-15-17 Egawa Shimamoto-cho Mishima-gun, Osaka 618-0013.

Received April 12, 2002

\section{SYNOPSIS}

The alignment of magnet powder such as $\mathrm{Nd}-\mathrm{Fe}-\mathrm{B}$ and $\mathrm{Sr}$-ferrite under applied magnetic field was investigated. Initial magnetization curves of the unfixed powder showed sudden increase of magnetization at a field named $H_{\text {rot }}$ which can be related to the beginning of rotation of the easy axis towards the applied field. Although the coercive force of $\mathrm{Nd}-\mathrm{Fe}-\mathrm{B}$ powder had changed by the substitution of $\mathrm{Nd}$ by $\mathrm{Dy}$, the value of $H_{\mathrm{rot}}$ remained stable. When the volume proportion of powder capsulated in a sample holder had increased, the rotation was suppressed and the magnetization decreased. Nd-Fe-B powder formed many stable columns which are parallel to the applied field. The diameter of the columns are about few hundred microns. Inside the columns, magnet powder formed small chains aligned parallel to the applied field. Based on the model experiment where the powder particles are simulated by small magnets, the process of alignment was classified to three steps: technical magnetization; rotation/movement; alignment.

KEY WORDS

$\mathrm{Nd}-\mathrm{Fe}-\mathrm{B}, \mathrm{Sr}$-ferrite, alignment, coercive force, magnetic dipole moment

\section{1 はじめに}

異方性焼結磁石の製造には，磁石粉末原料に磁場を加えな がら成形する磁場中成形とよばれる工程がある. 磁場中成形で は金型の空洞部(キャビティー)に磁場を発生するための電磁 石を備えた特殊な粉末プレス装置 (磁場プレス) を使用する. 磁場中成形は通常つぎの4つの一連の動作からなつている: (1) 金型の空洞部に磁石粉末を供給する; (2)供給された磁石粉末に 磁場を加えて配向する; (3)配向させた磁石粉末に圧力を加えて 成形する; (4)成形で得られたグリーンを金型からとり出す.こ れらのうち(2)の磁場中配向過程は,「一軸異方性を持つ単結晶 粒子の集合体に外部から磁場を印加して個々の粒子の磁化容 易軸の方向を磁場の方向に平行にそろえる操作」と定義する ことができる゙. 磁場は通常(3の加圧が終了するまで加え続ける.

磁場中配向, および成形によってえられたグリーンは焼結工 程をへて真密度に近いフルデンス磁石となる.このような工程 で製造される異方性焼結磁石の代表的なものにはNd-Fe-B系,
Sm-Co 系, フェライト系などがある. また, HDDR 法による 異方性磁粉をつかった Nd-Fe-B 系異方性ボンド磁石, あるい はSm-Fe-N系異方性ボンド磁石などの製造においても磁場中 成形がおこなわれている.

磁場中成形は異方性磁石の結晶配向度を決定する重要な工 程であるため, 配向度を高めるための工夫を加えたさまざま な磁場中成形技術が提案されている ${ }^{2-4)}$. また, 磁場中成形時 の磁石粉末粒子の挙動を計算機シミュレーションで解析する こともこころみられている5-9). しかし, 磁石粉末の磁場中で の挙動そのものを実証的に解析した研究は, 定量的な測定の 困難さもあってあまりみあたらない10).

われわれは，磁石粉末の配向挙動を解析するひとつのここ ろみとして試料振動型磁力計 (Vibrating Sample Magnetometer: VSM)による磁石粉末の初期磁化曲線の測定をおこなった. の結果, 低磁場における磁石粉末の技術磁化過程や, 保磁力と 配向挙動との関係などについて新たな知見が得られたので報 
告する.また，磁場中での磁石粉末の形態についても述へる。

\section{2 初期磁化曲線による配向挙動の解析}

$\mathrm{Nd}-\mathrm{Fe}-\mathrm{B}$ 系焼結磁石の原料粉末の個々の粒子は大部分を占 める $\mathrm{Nd}_{2} \mathrm{Fe}_{14} \mathrm{~B}$ 主相の単結晶とわずかな Nd-rich 相からなって いる. 前者は室温で強磁性を示し, しかも結晶磁気異方性か 極めて大きい。この性質を利用して粉末の初期磁化曲線から 原料粉末の配向挙動の解析をこころみた.

\section{1 実験方法}

初期磁化曲線を測定する試料粉末として Table 1 に示した 2 種類の粉末を用意した。いずれも参考文献と同様の方法に よって作製された焼結磁石用の乾燥原料粉末である. 次に， 内寸が $\phi 2.5 \times 8 \mathrm{~mm}$ のアクリル酸樹脂製のフ夕付き試料ホル ダーに, Nd-Fe-B 磁石粉末の場合は $30 \mathrm{mg}, \mathrm{Sr}$ フェライト磁 石粉末の場合は $20 \mathrm{mg}$ だけ挿入し，下記の a.〜 c. の 3 種類の 方法で調製した.

a. 試料とともにパラフィンを適量㨉入し,フタをした後, ドライヤーで試料ホルダー全体を加熱してパラフィンを溶融 させ，試料とよくなじませる．次に，試料ホルダーの $8 \mathrm{~mm}$ 方 向を重力に対して水平に保つとともに，同方向に平行に $1 \mathrm{MA} / \mathrm{m}$ の磁場を印加して試料粉末を配向させながら自然冷却し，パ ラフィンを固化させる．最後に，試料に交流隇衰磁場を加え て脱磁する.

b. a. と全く同様の方法で，たたし磁場を印加せずに試料を パラフィンで固定する.

c. パラフィンは使用せずに，試料のみを固定しないフリー な状態で封入する。

初期磁化曲線の測定には東英工業製の試料振動型磁力計 VSM-1 を使用した. 最大印加磁場は $1.26 \mathrm{MA} / \mathrm{m}$ ，ゼ口磁場か

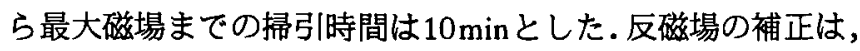
a. の試料の配向方向に磁場を印加したときの初期磁化曲線の 磁化の立ち上がり部分の微分透磁率が無限大になるように反 磁場係数 $N$ を調整し，そのときのNの值を全ての初期磁化曲線 に適用した.採用した值は, Nd-Fe-B粉末では $N=0.11, \mathrm{Sr}$ フェ

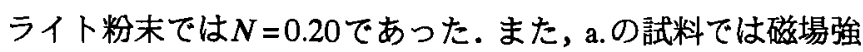
度 $5.2 \mathrm{MA} / \mathrm{m}$ のパルス磁場で着磁した後の減磁曲線も測定し, 固有保磁力 $H_{\mathrm{c}}$ を求めた.

\section{2 粉末固定試料の初期磁化曲線}

Fig.1に, Nd-Fe-B粉末の配向試料 a.について, 試料の配向
方向と，測定時に印加する外部磁場とのなす角度を変えて測 定した初期磁化曲線を示す. 角度がゼロの曲線と $90^{\circ}$ の曲線 はそれそれ磁化容易軸方向，および磁化困難軸方向の磁化曲 線に相当する。角度が $15^{\circ}$ 以下の曲線では，磁化の立ち上が り部分はほとんど $\mathrm{y}$ 軸と重なっている。これは, 試料粉末粒 子内での磁壁の移動が極めて容易であることを示唆している． また, これらの磁化曲線は, 単結晶試料の磁化曲線に比べる と磁気飽和に至る部分が丸くなっているのが特徽的である。 試料 a. は配向時に磁気㠅歴を受けていることに注意する必要 があるが，上に述へた初期磁化曲線の特徵は熱消磁状態の Nd-Fe-B 焼結磁石のそれと共通している. 印加磁場の方向か 容易軸から離れるにつれて，その方向に磁化することが次第 に困難になる。これは， Nd-Fe-B粉末の持つ強い結晶磁気異 方性により，パラフィンで固定された粒子の持つ磁気モーメ ントの向きを印加磁場の方向に容易に回転できないことを示 す.また，Fig.1のなかに比較のためにランダム試料b.の磁化 曲線も合わせてプロットしているが，この曲線のゼロ点に近 い部分は試料 a. の配向方向に対して $60^{\circ}$ の角度に外部磁場を 印加して測定した磁化曲線とほぼ一致している。

2.3 フリーな試料の初期磁化曲線

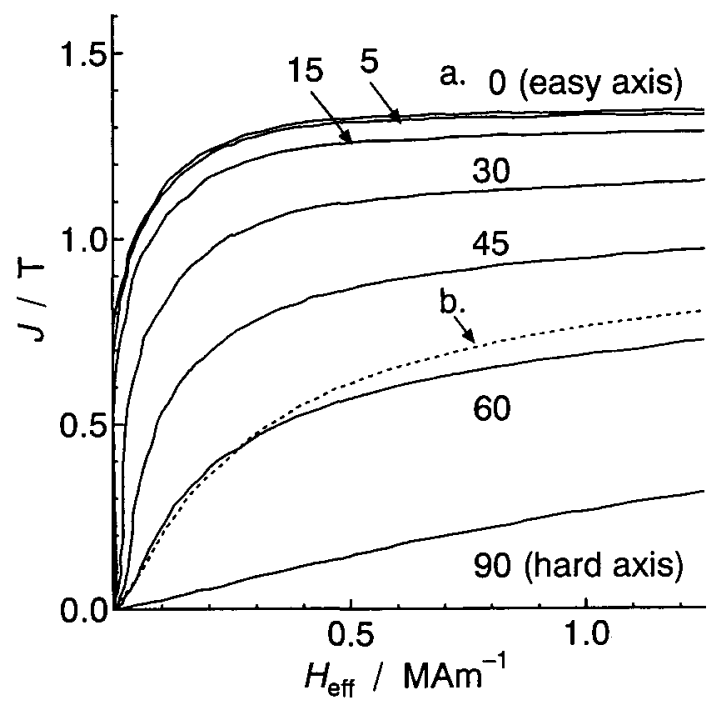

Fig.1 Initial magnetization curves of $\mathrm{Nd}-\mathrm{Fe}-\mathrm{B}$ powder a): fixed under magnetic field (solid), and b): fixed without magnetic field (doted). Angles between the alignment field and the measurement field are indicated.

Table 1 Properties of permanent magnet powder investigated.

\begin{tabular}{lccccc}
\hline & $\begin{array}{c}\text { Average } \\
\text { diameter } \\
(\mu \mathrm{m})\end{array}$ & $\begin{array}{c}\text { Intrinsic } \\
\text { density } \\
\left(\mathrm{Mg} / \mathrm{m}^{3}\right)\end{array}$ & $\begin{array}{c}\text { Saturation } \\
\text { magnetization } \\
(\mathrm{T})\end{array}$ & $\begin{array}{c}\text { Intrinsic } \\
\text { coercivity } \\
(\mathrm{kA} / \mathrm{m})\end{array}$ & $\begin{array}{c}\text { Reference } \\
\text { No. }\end{array}$ \\
\hline Nd-Fe-B & 3.0 & 7.5 & 1.35 & 56 & 3 \\
Sr ferrite & 0.75 & 5.0 & 0.41 & 102 & 11 \\
\hline
\end{tabular}


次に，ランダムに固定した試料b.と，フリーな状態の試料 c.の初期磁化曲線を比較した結果を Fig.2に示す.ゼロ点付近 での試料c.の磁化曲線はb.のそれと重なっているか，印加磁 場が約 $12 \mathrm{kA} / \mathrm{m}$ を越えると磁化が急激に增加し始める.これ は，固定試料と異なり自由に回転できる試料粉末がその磁化 容易軸の向きを外部磁場の方向にそろえようとするためであ る.すなわち，試料 c.の磁化曲線は磁石粉末の磁場中配向挙 動を反映している.いいかえれば，試料 c. の磁化が固定試料 b. と一致している間は，試料粉末の回転，つまり磁場配向が 全く進行していないと解积することができる．そこで，本論 文ではフリーな状態の試料c.の磁化が急激に増加し始めると きの外部磁場の大きさを粉末の回転(rotation)が始まる磁場と 見なして $H_{\mathrm{rot}}$ と定義する．ところで， $H_{\mathrm{rot}}$ のような磁化の変曲 点が表れることへの別の解釉として,VSMにおいて粉末試料 を固定しないことによる測定上の不具合ではないかという的 念がある.しかし，試料振動を伴わないBHトレーサーで測定 した初期磁化曲線においても Fig.2 と同等な值の $H_{\mathrm{rot}}$ が観察さ れており，VSMによる測定結果は信頼するに足りるものと考 えられる。

Srフェライト粉末で同様の測定をおこなった結果をFig.3に 示す. Nd-Fe-Bに比へてて飽和磁化が低く, 結晶磁気異方性か 小さいことを除けばFig.1, Fig.2の初期磁化曲線と似た傾向を 示している．ただし，容易軸方向に測定した試料 a. の磁化の 立ち上がりはグラフの $\mathrm{y}$ 軸と重ならない。これは，Sr フェラ イトの粉末が単磁区粒子となっており，磁化反転に要する外 部磁場が大きいことを示唆している．しかし，いったん磁化 反転してしまえは磁化は一気に進み，磁化曲線は角張ってい る.フリーな状態の試料 c.の $H_{\mathrm{rot}}$ の值は試料 a. の磁化反転か 起こる磁場の值よりもやや大きく, 粉末の回転は磁化反転が 起こった後で開始すると考えられる.

2.4 固有保磁力および充填率の影響

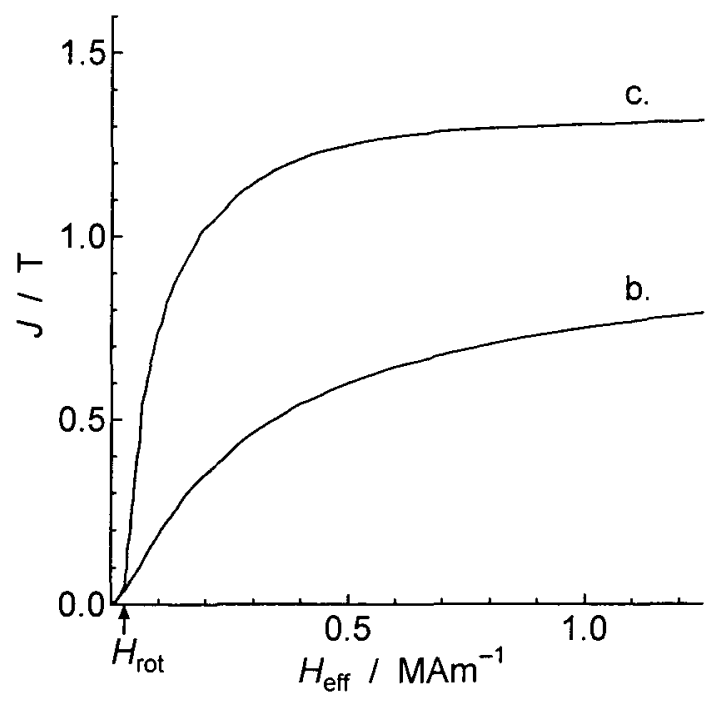

Fig.2 Initial magnetization curves of $\mathrm{Nd}-\mathrm{Fe}-\mathrm{B}$ powder $\mathrm{b}$ ): fixed without magnetic field, and c): unfixed. $H_{\text {rot }}$ indicates the magnetic field where the powder starts to rotate.
田口らは, $\mathrm{Sr}$ フェライト粉末の磁気的凝集が配向を妨げる とし，粉砕程みの導入により粉末の保磁力，および粉末の動 作点での磁束密度を低下させることにより配向度を高めるこ とができると述へている ${ }^{12}$. Nd-Fe-B粉末の保磁力は焼結磁 石のそれと比へて極めて低いが，それでもNdの一部をDy等の 重希土類で置換した組成系では粉末の固有保磁力が $200 \mathrm{kA} / \mathrm{m}$ を越えることがあり，配向への影響か懸念される.そこで，この ような保磁力の高いNd-Fe-B粉末の磁気特性を測定し， $H_{J}$ と $H_{\mathrm{rot}}$ との関係を求めた. 平均粒径が Table 1 の Nd-Fe-B粉末と同 等であり, かつ, 保磁力が $80 \sim 210 \mathrm{kA} / \mathrm{m}$ の範囲にある4種類 の Nd-Fe-B粉末の初期磁化曲線を測定した結果, 粒子の回転 が始まる外部磁場の值 $H_{\mathrm{rot}}$ は $14 \pm 4 \mathrm{kA} / \mathrm{m}$ の範囲にあり, 保磁 力が高いからといって粉末同士が磁気的に㠜集して配向しに くくなるといった傾向は見られなかった.これは, Nd-Fe-B系 の粉末の多くが多磁区構造をしており，低い磁場でも磁壁移 動により容易に技術磁化することができるためと考えられる．

さて，Fig.2で示したNd-Fe-B粉末の試料c.の充填率はたか だか $10 \mathrm{vol} \%$ 程度で，粉末がかなりフリーに動ける状態にあ る.一方，実際の Nd-Fe-B 焼結磁石の磁場中成形においては その倍以上の高い充填率で金型中に充填された状態の原料粉 末に対して磁場が印加される。そこで，配向挙動に対する粉 末の充填率の影響について調へるため, Nd-Fe-B 粉末の試料 c. の作製においてサンプルホルダーに挿入する試料の重量を 変えて充填率を $13 \sim 40 \mathrm{vol} \%$ の範囲で変化させたときの初期 磁化曲線を測定した. Fig.4にその結果を示す. 充填率が高く なるにつれて磁化の立ち上がりが緩やかになり， $H_{\mathrm{rot}}$ を示す変 曲点も不鮮明になる.特に，充填率か $40 \mathrm{vol} \%$ の曲線の磁化は 他に比べて極めて低くなる．これは，充填率が高くなること で粉末どうしの接触により磁場中での回転が妨げられた結果 であると考えられる．類似の現象がバインダーによって粉末 の回転が拘束された Nd-Fe-B粉末の造粒粉においても観察さ

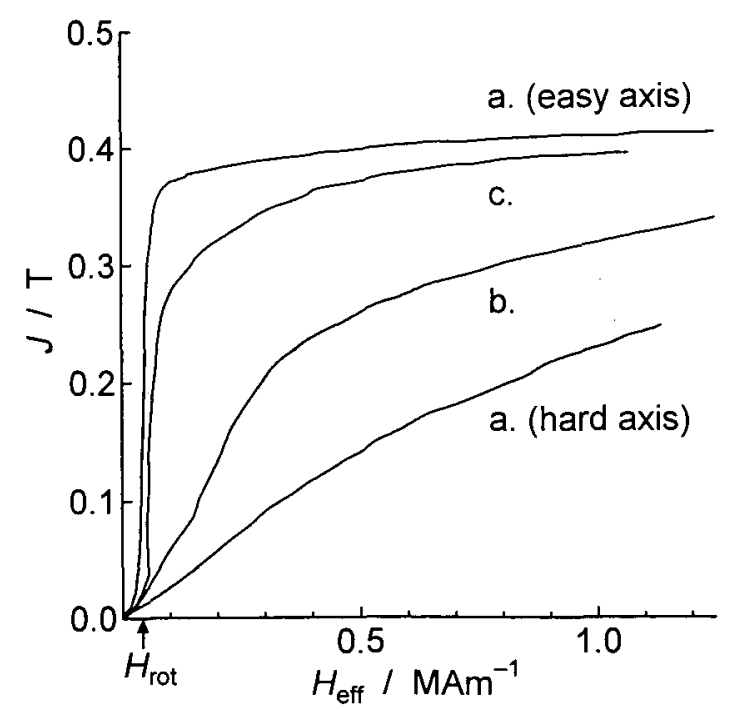

Fig.3 Initial magnetization curves of $\mathrm{Sr}$-ferrite powder. Symbols are the same as that in Figs. 1 and 2. 


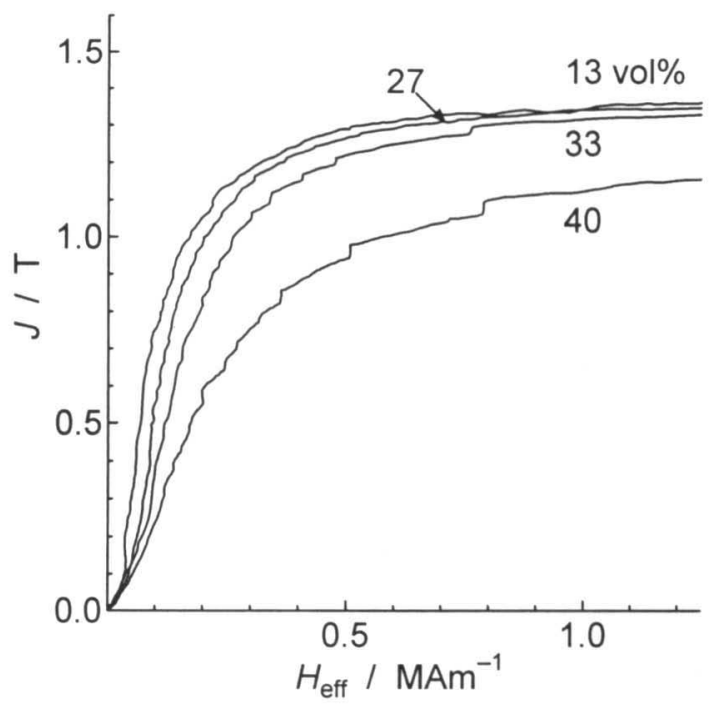

Fig.4 Initial magnetization curves of $\mathrm{Nd}-\mathrm{Fe}-\mathrm{B}$ powder capsulated in a sample holder. Volume fractions of powder are indicated.

中で回転を拘束されていたある大きさを持つ領域に含まれる 粒子が拘束にうち勝つだけのトルクを与えられて一斉に配向 したことを示唆している.この領域の大きさは, 磁化曲線の 段差の大きさから見てたかだか数 vol\%であると推測される. これだけの大きさを持つ段差は高充填率の試料にのみ観察さ れる. Nd-Fe-B粉末中の磁壁移動は容易であることから,こ の段差の原因が磁壁移動にともなうバルクハウゼンノイズで あるとは考えにくい. Fig.4の結果から, Nd-Fe-B原料粉末を $1.26 \mathrm{MA} / \mathrm{m}$ までの静磁界中で磁場配向する場合に配向度を大き く低下させないためには, 充填率を40vol\%よりも小さくする 必要があることがわかった.

\section{3 磁場配向した磁石粉末の形龍}

この章では, 磁場中で配向させた磁石粉末のとる形態を観 察した結果について述べる.

少量の Nd-Fe-B粉末をガラスびんに挿入して電磁石のつく

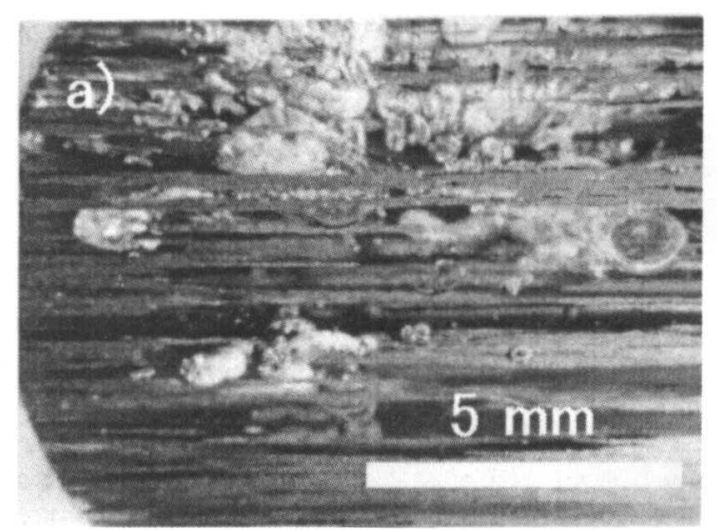

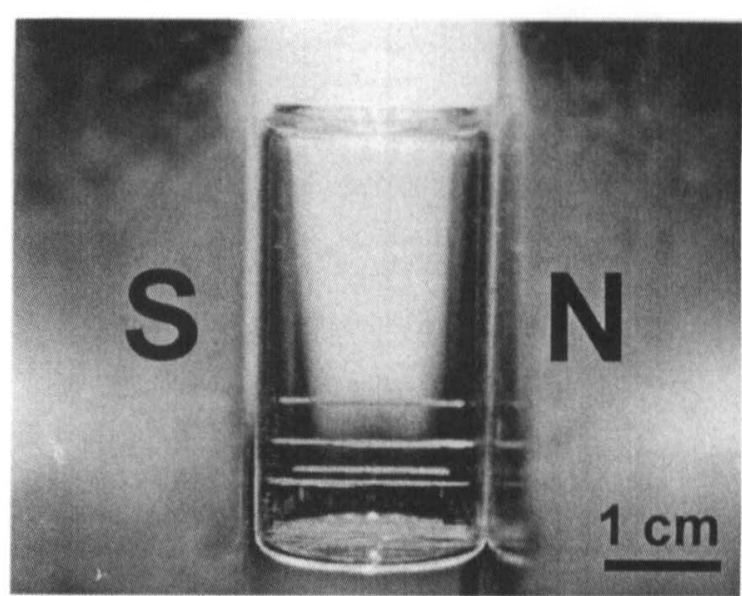

Fig.5 A photograph of columns made of Nd-Fe-B magnet powder sustained in a homogeneous magnetic field of $0.80 \mathrm{MA} / \mathrm{m}$ produced by an electromagnet. The powder was enclosed in a glass case. Polarities of the pole pieces are indicated.

る均一な磁場中に置くと, Fig.5の写真で示すように磁場と平 行方向に長く伸びた複数の柱状の粉末の束が形成される. 束 の太さはほぼ一定で，磁場を印加したままでガラスびんに振 動を加えると，互いに平行に並んだ束どうしの間に反発力が はたらいていて束どうしは決して近づかないことがわかる. また，あらかじめ束に垂直になるように紙片などを挿入して おき磁場を印加すると, 紙片を引き抜くのに大きな力を要す ることから，束を形成する粉末間には磁場と平行な方向に引 力がはたらいていることがわかる.

次に, $\mathrm{Sm}-\mathrm{Fe}-\mathrm{N}$ 粉末の磁場中配向時の形態を観察した Kobayashiら ${ }^{14)}$ の方法にならって, Nd-Fe-B粉末をエポキシ樹 脂と混合し, $0.8 \mathrm{MA} / \mathrm{m}$ の磁場を印加しながら樹脂を固化させ た試料を作製した．エポキシ樹脂には 2 液混合型のものを使 用した. 試料中の粉末の充填率は $5 \mathrm{vol} \%$ とした. 得られた試 料の印加磁場に平行, および垂直な面を研磨して光学顕微鏡 で観察した結果をそれぞれ Fig.6, Fig.7に示す.これらの断面 写真にはFig.5で見られたものと同様な粉末の束が形成されて

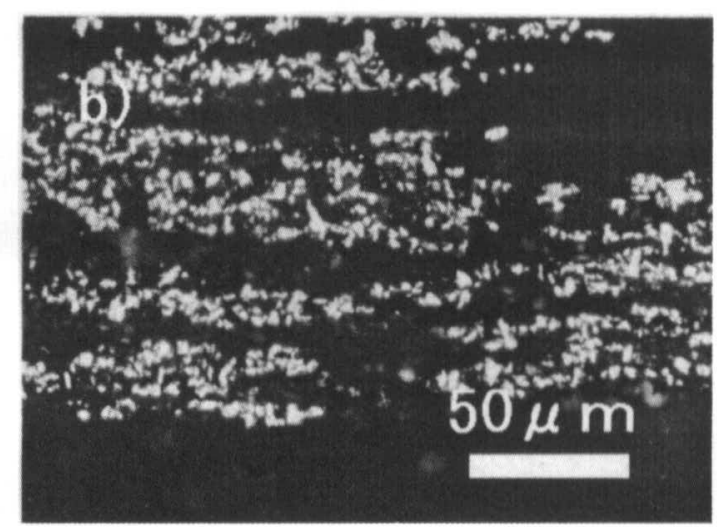

Fig.6 Cross section of aligned Nd-Fe-B powder fixed with epoxy resin. Magnetic field of $0.80 \mathrm{MA} / \mathrm{m}$ was applied to the horizontal direction. 

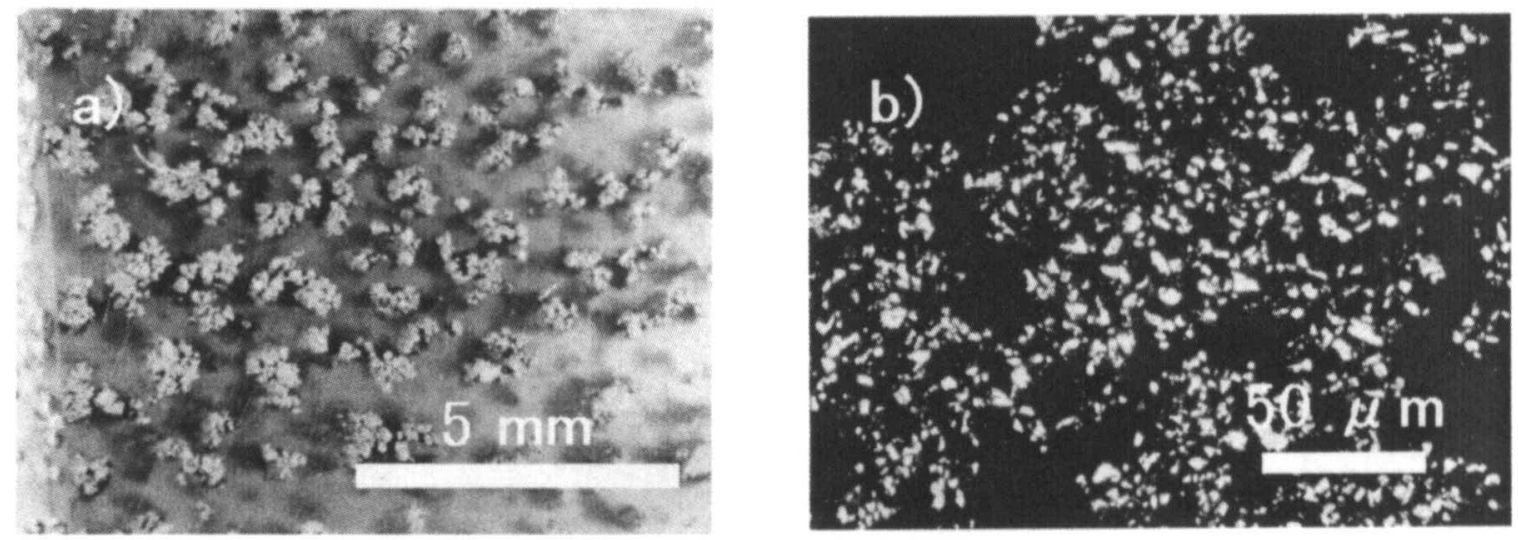

Fig.7 Cross section of aligned Nd-Fe-B powder fixed with epoxy resin. Magnetic field of $0.80 \mathrm{MA} / \mathrm{m}$ was applied perpendicular to the faces of photos.

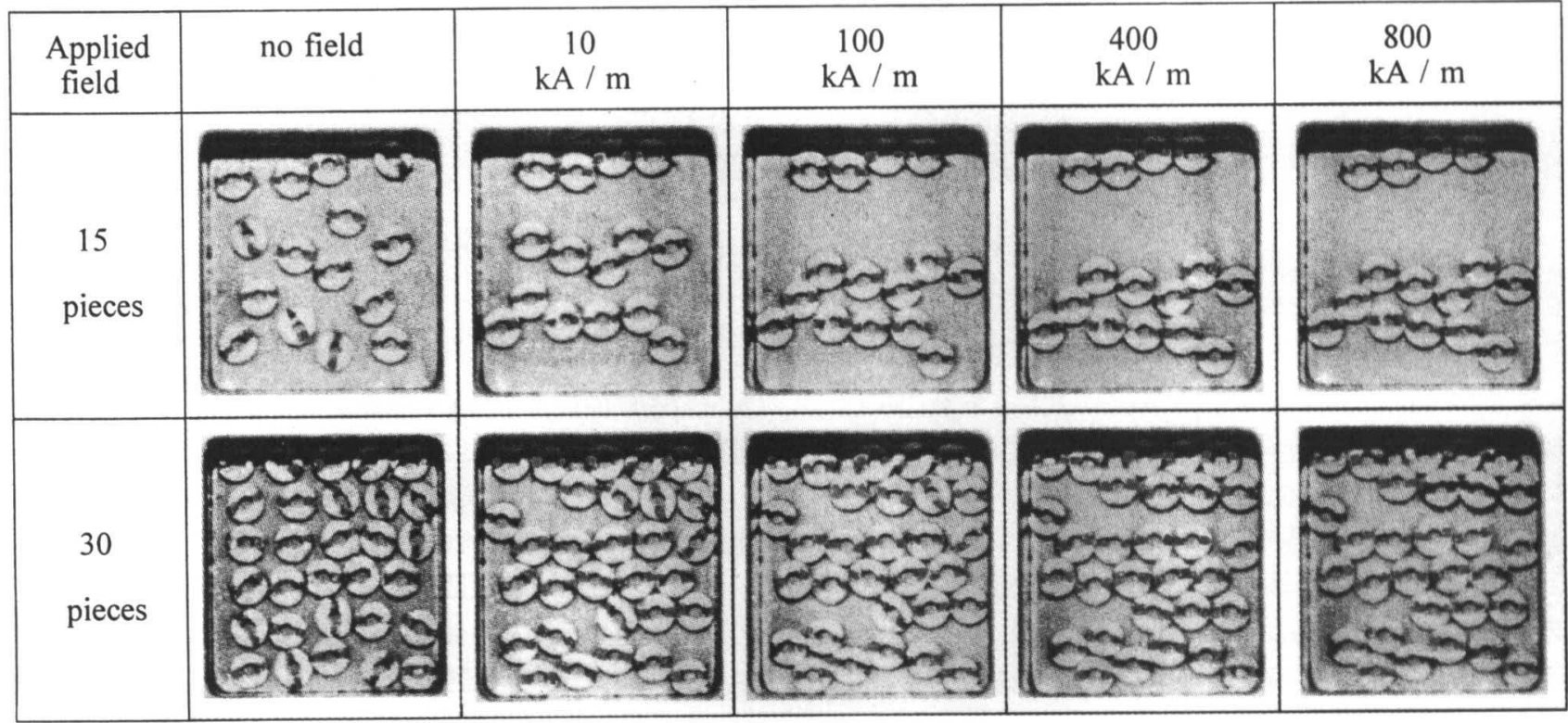

Fig.8 Magnetic alignment of demagnetized Nd-Fe-B sintered magnet rings. Magnetic field was applied to the horizontal direction.

いることがわかる. 束の太さは数 $100 \mu \mathrm{m}$ 程度で, 束どうしは 互いに自分の太さ程度の距離をへだてて存在している.Fig.6b) の高倍率の写真で見ると, 束の内部では個々の粉末粒子が磁 場に平行な方向に鎖状に連なっていることがわかる．また， 束の内部の粉末の分布は均一ではなく，磁場の方向に平行な すき間が多く見られる。

ところで，液体中に強磁性体微粒子を分散させた磁性流体 においても微粒子か磁場中で鎖状に配列することが知られて おり，その挙動は磁気双極子間の引力と斥力で説明すること ができると考えられている ${ }^{15)}$.すなわち，外部磁場の方向に 平行な磁気モーメントを持つ 2 個の粒子か，磁場方向に平行 な同一直線上に存在する場合は互いに引き合うために鎖の形 成にあずかり，また，磁場方向に垂直な同一面上に存在する 場合は互いに反発しあって束どうしの反発力の原因になる.

上に述べた挙動を小磁石を使ったモテル実験で再現してみ
よう. 実験には, 外径 $2.4 \mathrm{~mm}$, 内径 $1.0 \mathrm{~mm}$, 高さ $1.0 \mathrm{~mm}$ の, 径方向に異方性を持つ未着磁状態のNd-Fe-B焼結磁石を用い た。磁石の上面には磁化容易軸に平行になるような線をマー キングした. 非磁性材料でできた $15 \times 16 \mathrm{~mm}$ の大きさの容器 を電磁石の磁極間に水平に設置し, 内部に上記の磁石を 15 個 ないし 30 個ならべた. 次に, 容器の $15 \mathrm{~mm}$ 方向に平行に静磁 場を印加して磁場強度をゆっくりと增加させたときの内部の 磁石の動きをFig.8に示す.磁場を印加する前はランダムな方向 を向いていた小磁石は, 磁場強度 $10 \mathrm{kA} / \mathrm{m}$ においてはやくも磁 化容易軸の向きを磁場方向にそろえ始めている.この $10 \mathrm{kA} / \mathrm{m}$ という磁場の值は前節で述べたNd-Fe-B粉末の回転がはじま る磁場 $H_{\mathrm{rot}}$ に相当する. Fig.8の印加磁場 $10 \mathrm{kA} / \mathrm{m}$ のときの写 真をよく見ると, 磁石の数が 15 個の場合は回転がスムースに 起こっているのに対して, 30個の方は磁場の方向に充分にそ ろっていない磁石が見受けられる.これは, Fig.4で見られた 


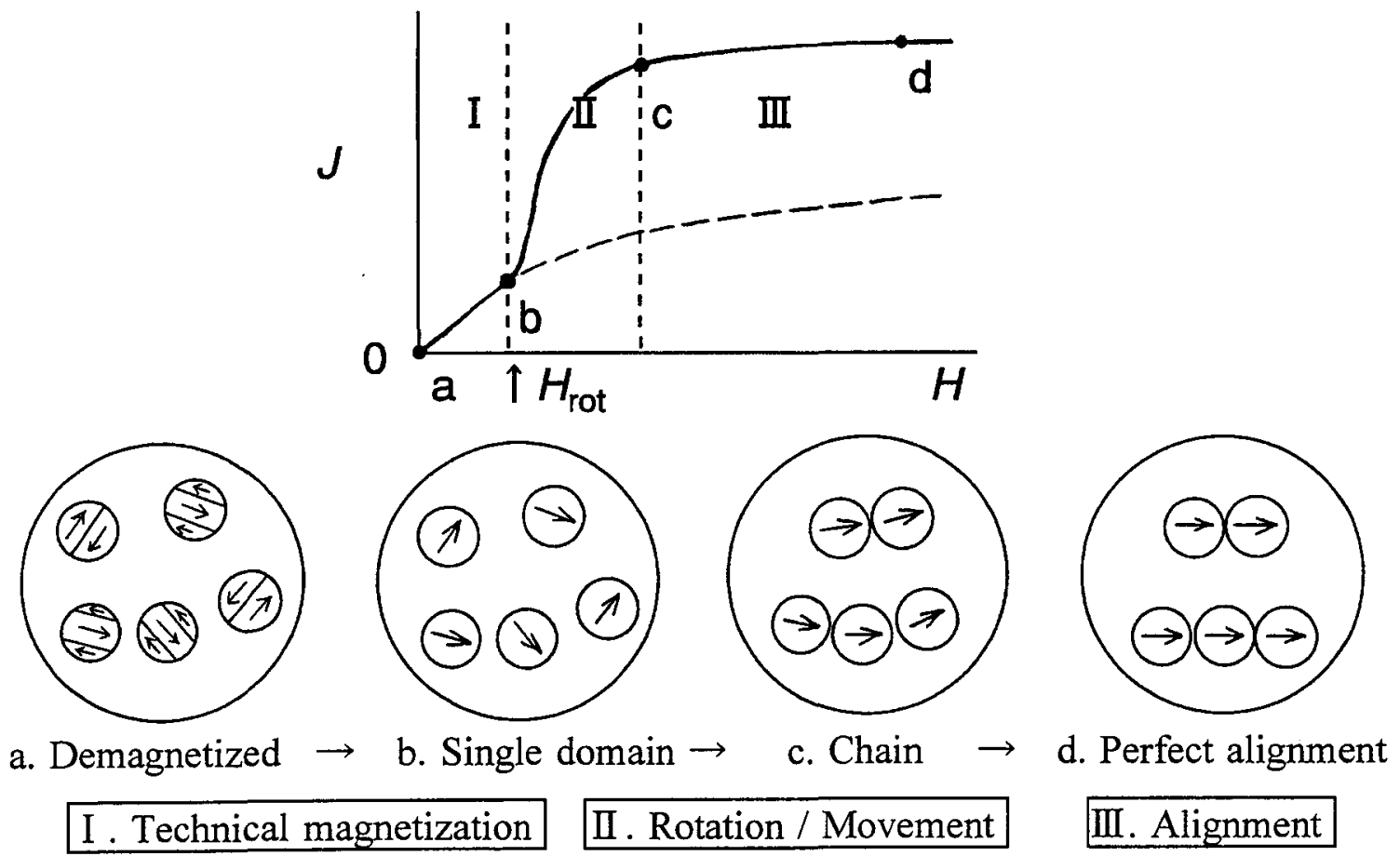

Fig.9 Sequential process in magnetic alignment of magnet powder.

粉末の充填率の違いをよく再現している.次に，鎖状の配列 の形成について見ると，外部磁場 $10 \mathrm{kA} / \mathrm{m}$ では回転の進行と 同時に鎖が形成されており，鎖の太さは磁石数 15 個の場合は 1 個分，30個の場合は 2 個分となっている．15個の磁石は磁 場を $100 \mathrm{kA} / \mathrm{m}$ に增加したときに 2 本の鎖が集まって 2 個分の 太さの鎖を形成している.この状況は磁場を $800 \mathrm{kA} / \mathrm{m}$ に增加 するまで変化しない. ちなみに, 磁場強度 $800 \mathrm{kA} / \mathrm{m}$ において 15個の磁石の細い方の鎖を太い方に指で近づようとしても 反発してできなかった。したがって，このモデル系では鎖の 太さは2本で安定していると考えられる.また，2個分の太さ の鎖をよく観察すると，磁石は隣の列の鎖を形成している磁 石と磁石の間に割り込むような位置に必ず存在していること がわかる.これは理にかなったことで，このような位置でと なりの鎖に近づくときに最もエネルギーのロスが少ないこと か磁気双極子モーメント間のエネルギーの計算からかかって いる19. しかし，Fig.6, Fig.7に見られたような数 $100 \mu \mathrm{m}$ 太さ の束がなぜ安定して存在するのかについてはいまのところ明 解な説明が得られておらず，今後の研究課題である.

\section{4 ま と め}

本研究では, 磁石粉末の磁場中配向挙動を明らかにするた めに, 配向した粉末の初期磁化曲線の測定と形態観察をおこ なった.配向過程について得られた知見をまとめてFig.9に示 す. 配向の第一段階は粉末の技術磁化過程であり, Nd-Fe-B 粉末では磁壁移動, $\mathrm{Sr}$ フェライト粉末では磁化反転によって
粉末粒子は回転を伴わずにほほ外部磁場の方向に磁化された 単磁区粒子となる. Nd-Fe-B粉末においては，粉末の保磁力 の大きさはこの段階の支配要因とはならない.第二段階では， 単磁区化した粒子がトルクを受けて回転を始めると同時に鎖 状に並び始める．第三段階では，鎖の中の粒子の磁化容易軸 の向きの整列が進み，完全配向に近づく. 第二, 第三段階で は磁場強度や粉末の充填率が支配要因となる。

\section{謝辞}

有益な助言をいただいた住友特殊金属侏の星島順，久村剛 之の両氏，ならびに実験をサポートしていたたいた同社の能 見正夫, 大森元生の両氏に感謝いたします．

\section{文献}

1）この定義にあてはまらない磁場中配向として，面内異方 性を持つ粉末を回転磁場を使って配向する方法が例えば， W.Qun, Z.Zhi-gang, L.Wei, X.K.Sun, Y.C.Chuang and F.R.de Boer: "Rotation alignment for measuring easy-plane magnetic anisotropy", J. Magn. Magn. Mat., 109(1992)59-63.

に提案されている.

2) M.Sagawa and H.Nagata: "Novel Processing Technology for Permanent Magnets", IEEE Trans. Mag., 29(1993)2747-2751.

3) Y.Kaneko and N.Ishigaki: "Recent Developments of HighPerformance NEOMAX Magnets", J. Mater. Eng. Performance, 3(1994)228-233. 
4) M.Takahashi, K.Uchida, F.Taniguchi and T.Mikamaoto: "High performance $\mathrm{Nd}-\mathrm{Fe}-\mathrm{B}$ sintered magnets made by the wet process", J. Appl. Phys., 83(1998)6402-6404.

5) 小寺秀俊, 小野山歩, 島進: " 粒子モデルによる圧粉成形 時の粒子配向と王粉体の磁気特性",粉体および粉末冶金, 42(1995)645-650.

6）小寺秀俊, 北原治倫, 島進: " 非円形粒子モテルを用いた 磁場中成形時の異形粒子挙動 ", 粉体および粉末冶金, 42 (1995)1019-1026.

7) 相澤龍彦: "粉末成形・粉末治金プロセス解析のための粉 粒体モテル開発とその応用", 粉体および粉末冶金, 43 (1996)1159-1164.

8) 野上裕, 近藤修, 高橋涉, 遠藤政治: "個別要素法を用いた 磁界中プレス成形時の粒子挙動解析", 粉体粉末冶金協会 平成 11 年秋季大会講演概要集, 吹田, (1999)106.

9) H.Kitahara, H.Kotera and S.Shima: "3-D Particulate Modeling for Simulation of Compaction in Magnetic Field", IEEE Trans. Magn., 36(2000)1519-1522.
10) 栗原史和, 小寺秀俊, 島進: "Nd-Fe-B 粉末の磁場中挙動 観察", 粉体粉末冶金協会平成 12 年秋季大会講演概要集, 大津 , (2000)124.

11）細川誠一, 豊田幸夫, 山下治, 沖本邦郎: "Srフェライトの 配向度に及ぼす粉砕粒度と成形磁界の影響", 粉体および 粉末治金, 45(1998)77-81.

12) 田口仁, 武石卓, 諏訪建一郎: " フェライト磁石の高性能 化に関する研究 ", 粉体および粉末冶金 , 44(1997)3-10.

13) 槙田顕, 西郷恒和, 能見正夫, 山下治: "スプレー造粒粉に よる Nd-Fe-B磁石の新しい成形技術", ニューセラミック ス , 11(1998)13-17.

14) K.Kobayashi, Xiao-lei Rao, J.M.D.Coey and D.Givord: "Susceptibility and magnetization processes in $\mathrm{Sm}_{2} \mathrm{Fe}_{17} \mathrm{~N}_{3}$ powders", J. Appl. Phys., 80(1996)6385-6390.

15) P.C.Scholten: "HOW MAGNETIC CAN A MAGNETIC FLUID BE?", J. Magn. Magn. Mat., 39(1983)99-106.

16) A.T.Skjeltorp: "Ordering phenomena of particles dispersed in magnetic fluids", J. Appl. Phys., 57(1985)3285-3290. 